\title{
Model Pendidikan Pancasila dan Bela Negara di UPN Veteran Yogyakarta dalam Menjawab Tantangan Kebangsaan
}

\author{
Lestanta Budiman*, Hari Dwi Laksana, Hastangka \\ Pusat Studi Pancasila, Universitas Pembangunan Nasional "Veteran" Yogyakarta \\ *Corresponding Author. Email: lestantabudiman@upnyk.ac.id
}

\begin{abstract}
This study aims to analyze the education model of Pancasila and National Defense in UPN Veteran. The research used descriptive method with a qualitative approach. The research was conducted in UPN Veteran Yogyakarta with its university student as the subject of the research. Data of the research were obtained through empirical and critical study and observation of Pancasila and National Defense learning. The primary data were obtained through interviews while the secondary data were obtained through literature reviews. The analysis technique used deductive-inductive analysis technique. The result of the research showed that the Pancasila and National Defense education model developed in UPN Veteran Yogyakarta consisted of two ways which were co-curricular and extracurricular programs.

Abstrak: Penelitian ini bertujuan untuk menganalisis model pendidikan Pancasila dan Bela Negara di UPN Veteran Yogyakarta. Metode Penelitian ini menggunakan metode deskriptif dengan pendekatan kualitatif. Penelitian ini dilakukan di UPN Veteran Yogyakarta dengan subyek penelitian mahasiswa. Data penelitian ini diperoleh dari kajian empirik, kritis, dan observasi dari pembelajaran pendidikan Pancasila dan Bela Negara. Sumber data penelitian berasal dari data primer melalui wawancara, data sekunder diperoleh dari kajian literature. Teknik analisis data yang digunakan dalam penelitian ini menggunakan teknik analisis deduktif-induktif. Hasil penelitian ini menunjukkan bahwa model pendidikan Pancasila dan Bela Negara yang dikembangkan di UPN Veteran Yogyakarta menerapkan dua jalur yaitu ko-kurikuler dan ekstrakurikuler.
\end{abstract}

\section{Article History}

Received: 29-03-2021

Revised: 09-05-2021

Accepted: 22-07-2021

Published: 07-09-2021

\section{Key Words:}

Education, Pancasila,

National Defences,

Wimaya.

\section{Sejarah Artikel}

Diterima: 29-03-2021

Direvisi: 09-05-2021

Disetujui: 22-07-2021

Diterbitkan: 07-09-2021

\section{Kata Kunci:}

Pendidikan, Pancasila, Bela

Negara, Wimaya.

How to Cite: Budiman, L., Laksana, H., \& Hastangka, H. (2021). Model Pendidikan Pancasila dan Bela Negara di UPN Veteran Yogyakarta dalam Menjawab Tantangan Kebangsaan. Jurnal Kependidikan: Jurnal Hasil Penelitian dan Kajian Kepustakaan di Bidang Pendidikan, Pengajaran dan Pembelajaran, 7(3), 545-554. doi:https://doi.org/10.33394/jk.v7i3.3600

https://doi.org/10.33394/jk.v7i3.3600

This is an open-access article under the CC-BY-SA License.

\section{Pendahuluan}

Isu-isu kebangsaan yang berkembang dan terjadi di Indonesia memiliki dinamika tersendiri. Potret isu kebangsaan tersebut dapat diamati dari berbagai pemberitaan yang muncul dalam kurun waktu 20 tahun terakhir. Kasus terakhir yang muncul polemik anggota Komisi Pemberantasan Korupsi (KPK) yang dianggap tidak lolos tes Wawasan Kebangsaan (Priyasmoro, 2021). Kasus tersebut menjadi isu kebangsaan status pegawai negara yang "dianggap" tidak memiliki wawasan kebangsaan yang memadai. Kasus sebelumnya terjadi persoalan transaksi uang dinar dan dirham di salah satu pasar Muamalah, Depok, Jawa Barat menjadi persoalan lunturnya rasa kebangsaan di kalangan masyarakat (Indah, 2021). Isu kebangsaan di wilayah timur seperti masih maraknya Kelompok Kriminal Bersenjata (KKB) di Papua yang mengakibatkan sejumlah korban warga sipil, guru, rumah pribadi dan sekolah dibakar, dan anggota TNI terkena tembak menjadi salah satu bentuk kerawanan sosial dan keamanan. Setidaknya tercatat sebanyak 46 kasus kekerasan sepanjang tahun 2020 yang dilakukan oleh KKB di Papua (Faris dan Rahmat, 2020). 
Rasa kebangsaan muncul dari wawasan yang dimiliki oleh seseorang tentang kondisi dan keadaan bangsanya. Wawasan dimaknai sebagai melihat atau memandang yang akan diwujudkan pada sikap dan perbuatan untuk mencapai cita-cita baik bersifat individu atau bersifat sosial atau bersama (LPPKB, 2011). Masalah kebangsaan dipahami sebagai persoalan sekterianisme, konflik antar suku, daerah, etnis, dan kelompok berpotensi pada persoalan lunturnya rasa nasionalisme (Maskur, 2012). Pada dasarnya ruang dan rasa kebangsaan dapat dibentuk dan diciptakan di ruang ruang kelas. Generasi muda memiliki peran penting dalam mentransformasikan nilai nilai kebangsaan tersebut dalam kehidupan masyarakat, kehidupan sehari hari.

Studi tentang isu isu kebangsaan sampai sejauh ini sangat minim untuk diakses dalam media elektronik. Proyek kebangsaan belum menjadi bagian penting dari kebijakan negara untuk mengelola generasi muda agar memiliki wawasan dan rasa kebangsaan sesuai dengan cita-cita dan tujuan nasional. Hal ini dapat terlihat dalam berbagai penelusuran literature dan referensi yang berkaitan dengan isu-isu kebangsaan dan sampai sejauh mana isu-isu kebangsaan diatasi dan dicegah melalui mekanisme seperti apa belum terlalu nampak. Proses penggalian problem mendasar kebangsaan dimulai dari ruang kelas. Analisis Ahmad (2020) menjelaskan bahwa imajinasi kebangsaan dapat tersumbat ketika ruang ruang tersebut tidak diberikan memadai untuk mengekpresikan nilai nilai, gagasan, ide, dan cita-cita. Hal ini dapat terjadi ketika kekuasaan tidak memberikan ruang imajinasi kebangsaan akan dengan mudahnya kita dapat temukan rakyat akan menolak untuk bersatu. Saat ini, anak muda tidak begitu tertarik dengan pemikiran dan jawaban yang njlimet. Generasi muda hari ini hanya berpikir bahwa kestabilan diperlukan untuk memudahkan kehidupan mereka di masa yang akan datang. Persoalan Pancasila tidak berdaulat di negeri sendiri karena ditemukan bahwa terjadi ketidakpahaman bangsa terhadap Pancasila sampai berdampak pada Pancasila tidak dapat bersaing di rumah sendiri dalam menghadapi isu-isu lokal, nasional, dan internasional (Purwadi dan Firdaus, 2015). Temuan Sari dan Lian (2017) menunjukkan bahwa kaum muda semakin banyak yang kurang faham dan kurang menjiwai terhadap permasalahan bela Negara. Padahal bela Negara merupakan tekad, sikap dan perilaku seluruh warga Negara yang dijiwai oleh rasa kecintaan kepada NKRI yang berdasarkan Pancasila dan UUD 1945.

Posisi Pendidikan memiliki peran penting untuk memperkuat nilai nilai kebangsaan. Untuk itu, memperkuat nilai nilai kebangsaan untuk menghadapi persoalan yang mendasar berkaitan dengan kebangsaan diperlukan suatu revolusi mental. Menurut Mulyasa (2017) Revolusi mental dalam pendidikan harus menumbuhkembangkan nilai-nilai Pancasila dan mengamalkan seluruh karakter bangsa secara utuh dan menyeluruh. Pendidikan Pancasila merupakan pendidikan nilai. Pendidikan Pancasila mulai berkembang dan dikenalkan pada dunia pendidikan melalui peraturan perundang-undangan yang berlaku sejak beberapa dekade. Peraturan perundang-undangan tersebut menjadi dasar yuridis dalam menyelenggarakan pendidikan Pancasila. Peraturan perundang undangan terbaru yang dibuat oleh Pemerintah melalui Undang-Undang Nomor 12 Tahun 2012 tentang Pendidikan Tinggi. Dalam peraturan perundang undangan tersebut menegaskan bahwa pendidikan Pancasila menjadi mata kuliah wajib dalam perguruan tinggi. Pasca terbitnya Undang-Undang ini berbagai perguruan tinggi melakukan penataan dan pengembangan mata kuliah Pancasila. Meskipun mata kuliah ini sudah pernah menjadi mata kuliah wajib umum namun pada beberapa periode sempat terhenti dengan terbitnya Undang Undang Nomor 20 Tahun 2003 tentang Sistem Pendidikan Nasional. Dalam Undang Undang Nomor 20 Tahun 2003 tentang Sistem Pendidikan Nasional, mata kuliah Pancasila dihapuskan sebagai mata kuliah wajib umum di perguruan tinggi dan juga pada pendidikan dasar sampai menengah. Hal ini yang menyebabkan model dan materi pembelajaran Pancasila di institusi pendidikan formal 
mengalami kekosongan untuk beberapa tahun. Pancasila dalam kehidupan bernegara secara historis diletakkan sebagai dasar filsafat negara (Budiman dan Hastangka, 2020). Acuan ini yang menjadi dasar dalam pengembangan dan pembelajaran pendidikan Pancasila di Perguruan Tinggi.

Perkembangan dan dinamika kehidupan berbangsa dan bernegara sejak Indonesia merdeka tahun 1945 mengalami berbagai tantangan kebangsaan. Isu kebangsaan pada fase pertama seputar merumuskan identitas dan jati diri sebagai bangsa yang merdeka dengan dasar dasar nilai nilai yang diletakkan. Fase ini mulai pada periode 1945. Kemudian Pancasila diletakkan sebagai dasar negara. Pancasila sebagai dasar negara menjadi tonggak penting dalam menjawab persoalan kebangsaan yang terjadi di zamannya. Pada fase kedua, paska 1945 terjadi persoalan terkait dengan isu-isu kebangsaan mulai dari periode 1945 sampai dengan 1950-an. Pada fase ini tantangan kebangsaan diperhadapkan dengan persoalan perjuangan untuk membangun kembali persatuan dan kesatuan. Berbagai peristiwa pada fase ini terjadi dalam bentuk perang revolusi fisik dan munculnya berbagai perjanjian perjanjian. Pada fase ketiga muncul berbagai isu kebangsaan yang mengarah pada ideologi. Ideologi kebangsaan kembali dipertanyakan pada periode 1950-an sampai dengan 1959 melalui perdebatan pada sidang dewan konstituante untuk kembali mempersoalkan ideologi. Pada fase berikutnya, isu kebangsaan muncul dengan basis ancaman pada ideologi seperti komunisme. Pada periode ini muncul pada tahun 1965-an. Fase pasca reformasi, isu kebangsaan radikalisme, fundamentalisme, politik identitas yang berkembang pada periode 1998 sampai sekarang. Hal ini juga diperkuat dengan pemaparan dari Marseno (2021) dalam Kongres Pendidikan, Pengajaran, dan Kebudayaan yang diselenggarakan oleh Universitas Gadjah Mada pada 4 Mei 2021 yang menjelaskan bahwa kampus menjadi medan pertempuran antar jati diri kampus dan paham paham radikalisme, terorisme, intoleransi, dan narkoba.

Universitas Pembangunan Nasional (UPN) "Veteran" Yogyakarta selama ini mengarahkan peserta didik untuk paham dan mengerti Pancasila sebagai dasar negara dan cinta tanah air untuk mewujudkan semangat bela negara. Pendidikan Pancasila diselenggarakan di semester 3. Sedangkan untuk semester 1 dan 2 difokuskan untuk memberikan pembelajaran Wimaya dan pendidikan kewarganegaraan. Mata Kuliah Pancasila merupakan mata kuliah wajib umum sebagai bagian untuk memberikan dasar dan nilai nilai dalam melaksanakan bela negara. Universitas Pembangunan Nasional Veteran Yogyakarta memiliki jati diri sebagai universitas bela negara untuk mewujudkan jati diri tersebut berbagai model pembinaan dan penguatan karakter kebangsaan dilakukan. Pendidikan Pancasila hadir sebagai upaya untuk menjawab tantangan kebangsaan yang terjadi. Persoalan dan isu-isu kebangsaan datang silih berganti sesuai dengan kondisi yang terjadi.

Adapun penelitian ini bertujuan untuk mendeskripsikan dan menguraikan tentang model pendidikan Pancasila dan Bela Negara dalam menjawab tantangan kebangsaan melalui studi di Universitas Pembangunan Nasional Veteran Yogyakarta. Model kajian ini menggunakan kajian dokumen dan deskripsi model pembelajaran yang dilakukan di kelas pada mata kuliah Pancasila. Penelitian ini menjadi menarik diteliti karena dalam kurun 20 terakhir pasca reformasi evaluasi dan pemetaan isu-isu kebangsaan yang berkembang di kalangan mahasiswa belum terlalu banyak dilakukan. Melalui penelitian ini diharapkan dapat menjadi baseline riset untuk mengetahui titik pijak isu isu kebangsaan yang dipahami oleh generasi muda dan berkembang di era paska reformasi. Penelitian ini berupaya untuk merumuskan secara sistematis dan memetakan tantangan kebangsaan yang muncul dan berkembang dalam masyarakat Indonesia kontemporer hari ini. Selain itu, penelitian ini 
memberikan dasar dasar sistematis atas tantangan kebangsaan hasil dari pandangan dari generasi muda.

\section{Metode Penelitian}

Penelitian ini menggunakan pendekatan kualitatif. Kegiatan penelitian ini dilakukan di Universitas Pembangunan Nasional (UPN) "Veteran" Yogyakarta dengan subyek penelitian mahasiswa UPN Veteran Yogyakarta. Data yang digunakan dalam penelitian ini diperoleh dari dokumen, jurnal ilmiah, dan observasi, serta wawancara yang dilakukan kepada mahasiswa. Analisis data ini menggunakan analisis deduktif-induktif. Analisis data dilakukan melalui reduksi data dan melakukan koding abstraksi, serta mengontekstualisasikan melalui penafsiran hasil data kajian dan wawancara dengan deskripsi (Creswell, 2015).

\section{Hasil Penelitian dan Pembahasan}

\section{Perkembangan dan Dinamika Isu Isu Kebangsaan}

Isu kebangsaan kurang popular dalam khasanah kajian ilmiah sebagai bagian dari topik atau judul utama. Berbagai studi dan penelusuran tentang kebangsaan yang lebih popular banyak muncul dalam pemberitaan di media cetak dan online. Hasil penelusuran yang dilakukan tentang rumusan isu kebangsaan belum nampak dalam kajian ilmiah termasuk jurnal jurnal yang ada. Padahal perkembangan dan dinamika isu isu kebangsaan selalu berubah dalam beberapa tahun terakhir ini. secara intensif, isu kebangsaan mulai muncul dan menjadi pemberitaan di media cetak dan online ketika paska reformasi. Lembaga Administrasi Negara (LAN) merumuskan definisi tentang kebangsaan bertitik tolak pada kesadaran. Kebangsaan akan terwujud ketika kesadaran menjadi bagian penting dalam kehidupan berbangsa dan bernegara.

Menurut Lembaga Administrasi Negara bahwa "Kesadaran berbangsa dan bernegara berarti sikap dan tingkah laku harus sesuai dengan kepribadian bangsa dan selalu mengkaitkan dirinya dengan cita-cita dan tujuan hidup bangsa Indonesia (sesuai amanah yang ada dalam Pembukaan UUD 1945)" (Ferrijana, Basseng, Triatmojo, anonim). Isu-isu kebangsaan muncul karena dianggap bahwa sikap dan tingkah laku tidak sesuai dengan kepribadian bangsa, serta cita-cita dan tujuan hidup bangsa Indonesia. Peristiwa bom bunuh yang terjadi di depan pintu Gereja Katedral Makassar, pada Minggu, 28 Maret 2021 pukul 10.00 WIT menjadi salah satu bentuk persoalan kebangsaan yang dihadapi bangsa Indonesia (Firdaus, 2021). Teror bom yang terjadi di Indonesia dalam kurun waktu 20 tahun terakhir ini menjadi dinamika isu kebangsaan sudah mengarah pada tindakan ancaman keamanan dan pertahanan negara, lemahnya rasa persatuan dan kesatuan, dan lunturnya jiwa bela negara. Tantangan kebangsaan terjadi karena orientasi dan wawasan kebangsaan yang dimiliki oleh masyarakat dan generasi muda secara khusus mengalami pergeseran. Pergeseran yang muncul dari cara pandang nasional menjadi cara pandang yang lebih ekslusif melihat unsur identitas ke-diri-an seperti suku, agama, golongan, dan kelompoknya. Apabila merujuk pada pemikiran Anis, Haikal, Joebagio (2016) memberikan kesimpulan bahwa kandungan wawasan kebangsaan sebagai cara pandang tentang diri dan lingkungannya pada dasarnya tidak didasarkan pada kesamaan suku bangsa, keturunan, kedaerahan, keagamaan ataupun kepercayaan serta adat istiadat atau kebudayaan daerah. Dengan cara pandang yang demikian akan tumbuh sikap hidup, cara berfikir dan cara kerja yang tidak diletakkan atas pengkotak kotakkan bangsa berdasarkan keterkaitan etnik, kedaerahan, keturunan, agama, dan kepercayaan.

Menurut Danniarti (2017) nilai nilai kebangsaan terkandung di dalam konsep Negara Kesatuan Republik Indonesia (NKRI), Pancasila, UUD 1945, dan Bhinneka Tunggal Ika 
menjadi bingkai persatuan dan kesatuan. Wawasan kebangsaan dan bela negara pada dasarnya didasari dari membiasakan belajar disiplin, kerjasama dalam solidaritas, tanggung jawab dan membentuk pribadi yang unggul kesadaran bela negara adalah berupaya untuk mempertahankan negara adalah berupaya untuk mempertahankan negara dari ancaman yang dapat mengganggu kelangsungan hidup bermasyarakat yang berdasarkan atas cinta tanah air (Wulandari, et al., 2021).

Orientasi dan pemahaman wawasan kebangsaan di kalangan generasi muda dapat ditelusuri dari hasil wawancara yang dilakukan untuk mendapatkan gambaran umum cara pandang mahasiswa yang kuliah di Perguruan Tinggi. Dari hasil wawancara dengan responden menemukan bahwa latar belakang responden yang berasal dari basis pendidikan keagamaan tidak banyak mendapatkan informasi dan pengetahuan tentang situasi dan kondisi kehidupan kebangsaan di Indonesia. Pada umumnya, mereka mendapatkan informasi dari luar atau media yang mereka akses hari ini seperti televisi, media sosial, dan internet. Salah satu responden yang pernah mendapatkan pendidikan pesantren sejak masa setara Sekolah Menengah Pertama (SMP) sampai dengan Sekolah Menengah Atas (SMA). Model pendidikan pada pesantren di lingkungan responden menggunakan model pendidikan salaf. Salaf yang dimaksud ialah pendidikan klasik dengan identitas pakaian menggunakan sarung, peci, dan dikedepankan masalah ubudiah. Ubudiah berbicara ritual agama (sholat, ngaji, baca quran, dzikir, tahajud). Pendidikan umum pada prinsip menjadi bukan hal yang utama atau nomor dua dalam kehidupan pendidikan di pesantren. Dalam pendidikan ini gurunya laki-laki dan lingkungannya laki-laki. Responden memiliki pengalaman tentang kehidupan kebangsaan. Di lembaga ini terdapat organisasi Iksass (Ikatan Santri Salafiah-Syafiah) kegiatannya pada umumnya bicara tentang kaderisasi, kepenulisan. Melalui wadah Iksass ini kita mengenal tentang negara dan bangsa, karena di Iksass se-nusantara karena masing masing delegasi dari berbagai daerah dan akhirnya kita tahu bahwa Bali tidak semuanya Hindu, Lombok memiliki budaya, Kalimantan berbeda tradisi. Para pelajar hanya sebatas paham pada identitas kebangsaannya. Pesantren responden merupakan salah satu pesantren tua yang pernah dilaksanakan mukhtamar NU tahun 1982. Sehingga pesantren ini sering didatangi oleh para pejabat negara.

Hasil pengalaman dan pengamatan yang diperoleh dari studi empiric melihat bahwa pemerintah itu berjalan apa adanya. Hal hal isu kebangsaan yang didengar sekedar persoalan konflik pilkada, pemilu. Sumber informasi melalui Koran atau cerita dari orang tua ketika berkomunikasi telpon. Responden yang berbasis pesantren memiliki pengalaman menarik untuk menjadi bahan refleksi dalam menangkap ide dan memori isu isu kebangsaan. Fase berikutnya isu-isu kebangsaan yang ditangkap oleh responden ketika masuk pada perguruan tinggi. Pada perguruan tinggi, responden ketika mengikuti orientasi mahasiswa seputar fungsi mahasiswa, sebagai agent of change, membangun kesadaran kritis, kesadaran sosial dan kesadaran intelektual. Kemudian masuk pada perkuliahan, pada proses perkuliahan mendapatkan banyak informasi dan mulai mengenal tentang isu isu SARA (Suku, Agama, Ras, dan Antar golongan). Pada perjalanan waktu, tahun 2014 dihadapkan pada pemilu. Politik identitas sebagai isu. Sejak itu, sebagai mahasiswa UPN Veteran Yogyakarta mulai sadar dan tidak terhanyut dari isu-isu SARA. Kemudian memfilter diri dan melakukan sosialisasi pentingnya persatuan dan kesatuan. Setelah itu mahasiswa UPN Veteran Yogyakarta diperhadapkan beberbagai kasus seperti bom bunuh diri, pembacokan pastor di Gereja, amuk di masjid. Setelah melihat isu-isu kemudian makin terpatri nilai-nilai nasionalisme. Kemudian ada upaya untuk ikut mengkampanyekan kebhinekaan, toleransi, dan kebangsaan dan berdirinya Pusat Studi Pancasila UPN Veteran Yogyakarta tahun 2017 dan ikut bergabung. 
Perkembangan dan dinamika isu-isu kebangsaan dari perspektif mahasiswa UPN Veteran Yogyakarta dipotret dan digambarkan menjadi 10 kategori sebagaimana tabel berikut

Tabel 1. 10 Persoalan/Isu Kebangsaan

\begin{tabular}{ll}
\hline No & \multicolumn{1}{c}{ Persoalan/Isu Isu Kebangsaan } \\
\hline $\mathbf{1 .}$ & Suku \\
$\mathbf{2}$ & Agama \\
$\mathbf{3}$ & Ras \\
$\mathbf{4}$ & Antar Golongan \\
$\mathbf{5}$ & Pendidikan \\
$\mathbf{6}$ & Lingkungan \\
$\mathbf{7}$ & Kebudayaan \\
$\mathbf{8}$ & Politik \\
$\mathbf{9}$ & Pertanian \\
$\mathbf{1 0}$ & Pertahanan dan Keamanan \\
\hline
\end{tabular}

Sumber: diolah dari hasil penelitian, 2021.

Berdasarkan hasil dari pemetaan dan identifikasi awal seputar isu-isu kebangsaan yang muncul dari pandangan mahasiswa UPN Veteran Yogyakarta melalui wawancara mendalam oleh salah satu aktivis Badan Eksekutif Mahasiswa (BEM) UPN Veteran Yogyakarta. Isu Suku menjadi pengamatan dari mahasiswa karena melihat masih munculnya arogansi kesukuan yang tinggi. Misalnya konflik Dayak dan Madura tahun 1998 yang terbawa ke kampus. Situasi ini muncul ketika mahasiswa Madura yang kuliah di UPN Veteran Yogyakartar bertemu dengan mahasiswa yang berasal dari Kalimantan khususnya suku Dayak. Nampak ada situasi kurang harmonis, eksklusif, dan penuh prasangka yang membuat perasaan kurang nyaman. Isu yang muncul terkait dengan tinggal di Asrama daerah. Kasus yang terjadi salah satu Asrama daerah Kalimantan yang tidak menerima suku Madura meskipun mereka lahir dan besar di Kalimantan karena kemungkinan tidak dianggap menjadi bagian dari bangsa atau satu daerah. Padahal Asrama daerah untuk memawadahi mahasiswa yang berasal dari daerah asal bukan dari genelogi asal suku atau darah kelahiran. Isu agama, ketika mencuatnya kasus persoalan antar agama seperti pengrusakan berbagai tempat ibadah, pembacokan pemuka agama akhirnya muncul sentimen mahasiswa agak kurang nyaman ketika bertemu, duduk, atau berbicara dengan rekan yang berbeda agama. Isu Ras, terdapat pengecualian terhadap teman teman yang berbeda suku seperti tempat kos yang tidak boleh untuk suku tertentu meskipun satu bangsa.

Isu antar golongan, arogansi fakultas yang muncul di beberapa fakultas di UPN Veteran Yogyakarta yang menyebabkan konflik antar mahasiswa yang berbeda Fakultas. Pemicunya konflik biasanya arogansi karena merasa superior, banyak pengikutnya, merasa jurusan yang dianggap anak emas (favorit) di mata pejabat Universitas. Kondisi ini tidak mencerminkan aspek nilai-nilai kebangsaan dan persatuan dan kesatuan. Isu pendidikan, tanggung jawab negara ialah mencerdaskan kehidupan bangsa, namun banyak mahasiswa yang cuti kuliah karena tidak bayar SPP/UKT bahkan ada yang berhenti. Kondisi ini akan berpotensi pada mereduksi nilai-nilai kebangsaan karena pendidikan semakin mahal dan sulit diakses. Materi yang disampaikan dosen sangat sedikit yang orientasinya membangun bangsa dan negara meskipun ada mata kuliah Pancasila. Isu lingkungan, mahasiswa UPN Veteran Yogyarta mencermati isu perampasan lahan produktif atas nama pembangunan seperti Kulon progo, kendeng. Isu kebudayaan, masih sedikit mahasiswa yang bangga memakai batik, menggunakan blankon, peci hitam. Tetapi mahasiswa mulai bangga mengenakan baju gamis. Isu politik, persoalan mendasar ialah politik identitas, saling menghayut, menyinggung isu agama, seperti munculnya hastag "pilihlah pemimpin yang Islam", hastag ini muncul ketika 
pemilihan presiden, Bupati, Gubernur, dan Presiden yang tersebar di HP dan reklame, dan poster yang ditempel atau virtual. Isu pertanian, persoalan impor beras masih dirasakan oleh mahasiswa. Kesadaran mahasiswa dalam melihat peristiwa dan persoalan rakyat dengan maraknya impor beras yang menyebabkan petani Indonesia merugi. Isu pertahanan dan keamanan, masuknya kapal asing masuk ke kedaulatan Indonesia, nelayan asing yang menangkap ikan di wilayah NKRI.

Problem kebangsaan yang telah terungkap dalam wawancara yang dilakukan kepada responden mahasiswa UPN Veteran Yogyakarta dan aktivis BEM memberikan gambaran umum tentang kondisi dan situasi yang terjadi di lingkungan perguruan tinggi tentang tantangan kebangsaan yang dihadapi oleh bangsa dan negara dari perspektif mahasiswa (Wawancara responden, 7 Januari 2021, pkl.4:23, di PSP UPN Veteran Yogyakarta).

\section{Model Pendidikan Pancasila dan Bela Negara di UPN Veteran Yogyakarta}

Universitas Pembangunan Nasional Veteran Yogyakarta merupakan kampus bela negara yang meletakkan dasar dan nilai-nilai Bela negara serta kejuangan. Pancasila menjadi salah satu dasar dalam menggerakkan nilai nilai bela negara. Pendidikan bela negara diberikan kepada mahasiswa sebagai upaya untuk menumbuhkan semangat dan kesadaran bela negara di kalangan generasi muda (Budiman dan Hastangka, 2019). Kesadaran bela negara dimaknai sebagai upaya untuk mempertahankan negara kita dari ancaman yang dapat mengganggu kelangsungan hidup bermasyarakat yang berdasarkan atas cinta tanah air. Kesadaran bela negara juga dapat menumbuhkan rasa patriotisme dan nasionalisme di dalam diri masyarakat (Ferrijana,Basseng,Triatmojo, 2019). Berbagai model pendidikan Pancasila dan Bela negara juga ditawarkan di sekolah melalui pendekatan kegiatan di luar kelas seperti ekstrakurikuler. Sebagaimana riset yang dilakukan Suwandoko, Yusnanto, dan Widiyanto D (2020) menjelaskan penguatan sikap bela negara untuk menangkal radikalisme dapat dilakukan dengan membangun sikap yang harmonis antara kepala sekolah, guru, dan siswa serta melalui kegiatan Pramuka. Untuk itu, Pancasila dan bela negara menjadi bagian penting dalam proses pendidikan untuk menanamkan nilai nilai kebangsaan dan bela negara. Model pendidikan Pancasila yang dikembangkan di UPN Veteran Yogyakarta selama ini dalam bentuk di kelas. Metode pembelajaran yang berlangsung secara umum melalui ceramah, mahasiswa untuk bisa membeli buku terkait Pancasila dan butir-butir Pancasila. Materi secara umum yang diberikan tentang arti dan lambang negara, teritorial. Sedangkan materi bela negara dalam bentuk Wimaya, model pendidikan ceramah, buku diberikan oleh kampus. Materi bela Negara antara lain, nilai nilai kejuangan, disiplin, dan kreativitas. Materi Pancasila sebagaimana merujuk pada buku ajar mata kuliah wajib umum Pendidikan Pancasila yang diterbitkan Dikti tahun 2016 juga menekankan pada wawasan Pancasila sebagai dasar negara, ideologi negara, sistem filsafat, sistem etika, dan dasar nilai pengembangan ilmu (Munir, Mustansyir, Nurdin, 2016).

Proses pembelajaran yang dikembangkan dimulai dari gagasan bahwa aspek input ialah mahasiswa baru yang masuk dan diterima di UPN Veteran Yogyakarta melalui berbagai jalur dan berlatar belakang daerah, budaya, dan pendidikan yang beragam mulai dari SMA, SMK dan jurusannya ada IPA dan IPS. Pada tahap awal mereka akan mendapatkan orientasi sebagai mahasiswa baru dengan pengenalan terhadap kehidupan kampus. Setelah itu mereka akan masuk pada materi penguatan kebangsaan yang disebut MKWU yang terdiri Pancasila. Luarannya ialah menghasilkan lulusan yang memiliki jiwa bela negara. 


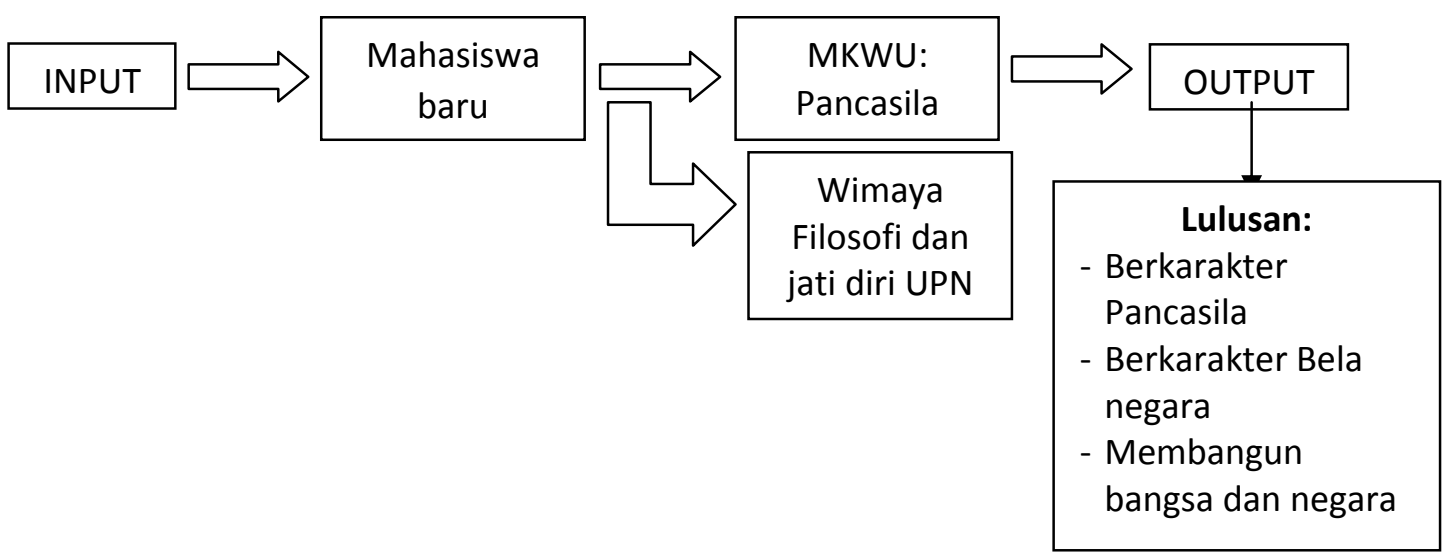

Gambar 1. Alur Model Pendidikan Pancasila dan Bela Negara

Berdasarkan gambar 1 di atas menunjukkan bahwa model pendidikan Pancasila dan Bela negara diberikan dengan bentuk kurikulum wajib yang melalui pembelajaran. Pembelajaran dilaksanakan melalui tatap muka dan kegiatan pendukung dalam pembelajaran baik di dalam kelas maupun di luar kelas. Kegiatan di kelas dilakukan dengan memberikan materi kepada mahasiswa kemudian bentuk kegiatan kelas berupa diskusi kelompok, presentasi kelompok, kegiatan mandiri dengan berkunjung ke tempat tempat bersejarah dan museum. Kegiatan pendalaman lainnya dengan memberikan pengetahuan dan wawasan berupa wimaya. Wimaya merupakan materi sejarah, filosofi, jati diri, dan nilai nilai UPN Veteran Yogyakarta. Dalam pendidikan Pancasila dan Bela negara diarahkan untuk memperkuat nilai nilai Pancasila. Untuk itu, materi dasar dalam pendidikan Pancasila ialah materi tentang sejarah Pancasila dan Pancasila sebagai dasar negara. materi dasar ini menjadi penting untuk memberikan landasan kepada mahasiswa tentang hakikat Pancasila dalam kehidupan bernegara. Menurut Dewi dan Handayani (2021) menjelaskan bahwa Pancasila sebagai dasar negara dan ideologi nasional membawa konsekuensi logis bahwa nilai nilai Pancasila dijadikan sebagai landasan pokok dan fundamental bagi penyelenggaraan negara Indonesia. Nilai-nilai Pancasila ini menjadi dasar dalam upaya untuk penguatan dan pelaksanaan bela negara dalam kehidupan masyarakat. Menurut Sukawati (2021), aktualisasi nilai nilai Pancasila dapat dilakukan dalam bentuk kegiatan di luar kelas seperti pelatihan bela negara, kegiatan di luar sekolah, dan ekstrakurikuler. Model Pendidikan Pancasila dan bela negara yang diselenggarakan di UPN Veteran Yogyakarta menggunakan dua pendekatan utama yaitu pendekatan kurikuler dan ekstrakurikuler. Pendekatan kurikuler melalui kurikulum wajib dan pendekatan ekstrakurikuler melalui pendekatan kegiatan di luar kelas atau di luar kampus.

\section{Kesimpulan}

Hasil penelitian ini menyimpulkan bahwa model pendidikan Pancasila dan Bela Negara yang berkembang dan dikembangkan di Universitas Pembangunan Nasional Veteran Yogyakarta menerapkan prinsip-prinsip historitas bela negara, jati diri,dan filosofi pendirian Universitas Pembangunan Nasional Veteran Yogyakarta. Pendidikan Pancasila sebagai mata kuliah wajib umum menjadi fondasi dalam pengajaran dan pembelajaran Bela Negara. Dalam konteks Bela negara sebagai mata kuliah penciri institusi diberikan dalam bentuk materi Wimaya (Widya Mwat Yasa). Model yang terbentuk dalam pendidikan Pancasila dan Bela Negara untuk menjawab tantangan kebangsaan dilakukan melalui ko kurikuler dan ekstrakurikuler. 


\section{Saran}

Penelitian ini sebatas penelitian yang bersifat ekploratif dan pemetaan awal untuk mendeskripsikan dan mendokumentasikan tentang model pendidikan Pancasila dan Bela Negara yang saat ini ada dan berkembang di UPN Veteran Yogyakarta. Untuk itu Kementerian Pendidikan dan Kebudayaan dan Kementerian Pertahanan Republik Indonesia perlu melakukan penelitian yang mendalam bersifat pemetaaan secara komprehensif dan menyuluruh dengan menggunakan survei kepada seluruh mahasiswa, tenaga pendidik, dan dosen Pancasila dan Bela Negara di Perguruan tinggi di Indonesia sehingga dapat dipotret tentang bagaimana orientasi dan arah pendidikan Pancasila dalam memperkuat nilai nilai kebangsaan dan bela negara di kalangan generasi muda.

\section{Daftar Pustaka}

Anis, Madhan., Haikal, Husein., Joebagio, Hermanu. (2016). Implementasi Wawasan Kebangsaan dalam Pembelajaran Sejarah Di Pondok Pesantren(Studi Kasus Di Sma Al-Muayyad Surakarta dan SMA Muhammadiyah Boarding School Yogyakarta), Historika: Journal of History Education Research.Vol.18, No.1, 2016, hal.11-22.

Ahmad. Kamaruzzaman Bustamam. (2020). Mengurai Benang Kusut Masalah Kebangsaan, Sumber: https://sagoe.id/mengurai-benang-kusut-masalah-kebangsaan/, diakses 9 Mei 2021.

Budiman. L., Hastangka. (2019). Curah Gagasan Seputar Pemikiran Tentang Pancasila dan Bela Negara. Yogyakarta: Pusat Studi Pancasila UPN Veteran Yogyakarta.

Budiman, L., Hastangka. (2020). Buku Ajar Pendidikan Pancasila. Yogyakarta: Lembaga Penelitian dan Pengabdian Kepada Masyarakat (LPPM) UPN Veteran Yogyakarta.

Creswell.John W. (2015). Penelitian Kualitatif \& Desain Riset Memilih Di Antara Lima Pendekatan. Yogyakarta: Pustaka Pelajar.

Danniarti, Rahma. (2017). Implementasi Nilai-Nilai Pancasila sebagai Pendukung Tumbuh Kembang Wawasan Kebangsaan pada Mata Pelajaran PPkn Di SMP Negeri 7 Palembang, JMKSP Jurnal Manajemen, Kepemimpinan, dan Supervisi Pendidikan, Volume 2, No. 2, Juli-Desember 2017, hal. 187-203.

Dewi. D. A dan Handayani. P.A. (2021). Implementasi Pancasila Sebagai Dasar Negara, Jurnal Kewarganegaraan Vol. 5 No.1 Juni 2021, hal.6-12.

Ferrijana.Sammy., Basseng., Sejati Triatmojo. (2019). Modul Wawasan Kebangsaan dan Nilai nilai Dasar Bela Negara. Jakarta:Lembaga Administrasi Negara.

Firdaus.,Fahmi. (2021). Ini Kronologi Bom Bunuh Diri Gereja Katedral Makassar. Sumber:https://news.okezone.com/read/2021/03/28/609/2385326/ini-kronologi-bombunuh-diri-gereja-katedral-makassar, diakses 29 Maret 2021 7:44.

Indah. Andhike. (5 Februari 2021). Transaksi Uang Dinar dan Dirham di Indonesia Menyalahi Undang-Undang, Begini Kata Pakar Ekonomi, sumber: https://jogja.tribunnews.com/2021/02/05/transaksi-uang-dinar-dan-dirham-diindonesia-menyalahi-undang-undang-begini-kata-pakar-ekonomi, diakses 9 Mei 2021.

LPPKB. (2011). Pancasila. Lembaga Pengkajian dan Pengembangan Kehidupan Bernegara: Jakarta: LPPKB.

Maskur.Ahmad. (2012). Masalah Kebangsaan. Harian Umum Suara Karya, Senin 17 Desember 2012.

Merseno. Djagal Wiseso. (2021). Sambutan Pra Kongres V Pendidikan, Pengajaran,dan Kebudayaan. Webinar Nasional Seri \#3 Rangkaian Kongres V Pendidikan, 
Pengajaran, dan Kebudayaan Tahun 2021. Sumber: https://www.youtube.com/watch?v=nn0X2rnowu4.

Munir,Misnal., Mustansyir, Rizal., Nurdin Encep Syarief. (2016). Buku Ajar Mata Kuliah Wajib Umum Pendidikan Pancasila. Jakarta: Direktorat Jenderal Pembelajaran dan Kemahasiswaan Kementerian Riset, Teknologi, dan Pendidikan Tinggi Republik Indonesia.

Mulyas,. Enco. (2017). Revolusi Mental dalam Pendidikan untuk Merevitalisasi Nilai-Nilai Pancasila dan Menumbuhkembangkan Wawasan Kebangsaan, Prosiding Seminar Nasional 20 Program Pascasarjana Universitas PGRI Palembang 25 November 2017. Hal.1-8.

Purwadi. H dan Firdaus. A.G. (2015). Konsekuensi Transplantasi Hukum terhadap Pancasila sebagai Norma Dasar dan Hukum Lokal, Yustisia. Vol. 4 No. 1 Januari - April 2015, hal. 73-88.

Priyasmoro, Muhammad Radityo. (05 Mei 2021). KPK: 75 Pegawai Tidak Lulus Tes Kebangsaan Menjadi ASN, https://www.liputan6.com/news/read/4550915/kpk-75-pegawai-tidak-lulus-teswawasan-kebangsaan-menjadi-asn, diakses 9 Mei 2021.

Republik Indonesia. (2012). Undang-Undang Nomor 12 Tahun 2012 Tentang Pendidikan Tinggi.

Rahmat.Agus., Faris, Ahmad Farhan. (15 September 2020). Sudah 46 Kasus Kekerasan Dilakukan KKB Papua Selama 2020, https://www.viva.co.id/berita/nasional/1302405sudah-46-kasus-kekerasan-dilakukan-kkb-papua-selama-2020, diakses 9 Mei 2021.

Sari.W.A, Lian.B. (2017). Menjadikan Mata Kuliah Pendidikan Pancasila Sebagai Media Penanaman Nilai-Nilai Bela Negara, JMKSP Jurnal Manajemen, Kepemimpinan, dan Supervisi Pendidikan, Volume 1, No. 1, Juli-Desember 2017. Hal. 303-314.

Sukawati, Ani. (2021). Aktualisasi Nilai Nilai Pancasila dan Kesadaran Bela Negara Alumni SMK N 1 Temanggung Angkatan 43, Jurnal Pancasila dan Bela Negara, Vol.1.No.1 (2021), hal. 7-26.

Suwandoko, Yasnanto, Widiyanto. D. (2020). Penguatan Sikap Bela Negara Siswa Dalam Menangkal Radikalisme, Jurnal Kalacakra Volume 01, Nomor 01, 2020, pp: 25-31.

Wulandari, F. Wahyuni, R. Susanto, H. Suwanto. I. (2021). Sosialisasi Bela Negara Wawasan Kebangsaan dan Nilai Nilai Dasar di SMP N 1 Jagoi Babang Kabupaten Bengkayang, Al Khidmat: Jurnal Ilmiah Pengabdian Kepada Masyarakat, Vol.4 No.1 Tahun 2021, pp:1-7. 